ORIGINAL ARTICLE Volume 9 Issue 12017

DOI: 10.21315/eimj2017.9.1.6

\section{ARTICLE INFO}

Submitted: $14-07-2016$

Accepted: 09-02-2017

Online: $31-03-2017$

\title{
The Trends of Use of Social Media by Medical Students
}

\author{
Safaa El Bialy, Abdul Rahman Ayoub \\ Division of Clinical and Functional Anatomy, Department of \\ Innovation in Medical Education, Faculty of Medicine, University of \\ Ottawa, Ottawa, Canada
}

To cite this article: El Bialy S, Ayoub AR. The trends of use of social media by medical students. Education in Medicine Journal. 2017; 9(1): 59-68. https://doi.org/10.21315/eimj2017.9.1.6

To link to this article: https://doi.org/10.21315/eimj2017.9.1.6

\begin{abstract}
Introduction: As the online environment has evolved, the use of social networking sites (SNSs) has been integrated into the methods of teaching. Students across the world are currently using SNSs to enhance their learning. Objective: This study sought to explore the students' use of social media, in particular that of Facebook groups in medical education at the University of Ottawa. Methods: Pre-clerkship medical students $(n=160)$ were surveyed regarding the trends of use of SNSs in their learning. The survey consisted of 23 questions (Likert-style, multiple choice, yes/no, and short answer questions). Results: $94 \%$ of respondents use SNSs to facilitate their learning with Facebook $(n=98$, $97 \%)$. Students mostly use Facebook groups for histology (30\%), physiology (21\%), etc. They mostly use SNSs for these particular subjects because the material posted is engaging. Sixty percent $(60 \%)$ of students use SNSs to communicate with their colleagues and 59.8\% stated that they prefer Facebook groups over pages. They prefer sample tests/quizzes and study guides (65.6\%), followed by explanatory comments and an answer to a question (54.2\%), etc. The downside of the use of social media in education is distraction and privacy issues. Conclusion: SNSs are used by the majority of students to enhance their learning, but to use them to their fullest; the material posted has to be concise, engaging and aligned with the learning objectives. Social media are contemporary and efficient communication tools that educators cannot overlook; the challenge is to choose the right platform, the amount and quality of the information shared to ensure optimal benefit and collaboration of the students.
\end{abstract}

Keywords: Medical education, Social media, e-Learning

CORRESPONDING AUTHOR Safaa El Bialy (MD, PhD), Division of Clinical and Functional Anatomy, Department of Innovation in Medical Education, Faculty of Medicine, University of Ottawa, Ottawa, Canada | Email: selbialy@uottawa.ca 


\section{INTRODUCTION}

Over the past decade, young adults remained as the age group that is most likely to go online even as the internet population has grown, and even as other age cohorts such as adults (65 years old and older) have increased the percentage of their populations online (1). As the online environment has evolved, the use of social media such as Facebook and Twitter has been integrated into the methods of teaching and learning environment (2). Students across the world in various disciplines are currently using social media sites to enhance their learning experience. This is also the case for medical students where learning is also taking place outside the traditional classroom. The use of innovative social networks such as Facebook, Twitter, content-sharing sites (YouTube) and cloud storage sites (Google Docs) have allowed students to rapidly join online learning communities and become highly engaged. It has helped medical learners to access information to supplement their classroom learning.
These innovative technologies provide digital environments that allow participants to interact with one another and enhance their offline relationships with ease (3). These relatively new Web environments provide new ways for accessing, acquiring, sharing, and storing information. As problem-based learning, students are continually encouraged to look for additional information resources to support learning tasks (4), however, few studies to date have examined why or how students use social networking sites (SNSs) for learning. There are numerous social media sites such as Twitter, Myspace, Instagram and Facebook. The most popular social media site among users is Facebook. As of July 2016, Facebook reported that it has 1.71 billion active monthly users. Figure 1 shows the number of monthly active Facebook users worldwide as of second quarter 2016 (in millions) (5).

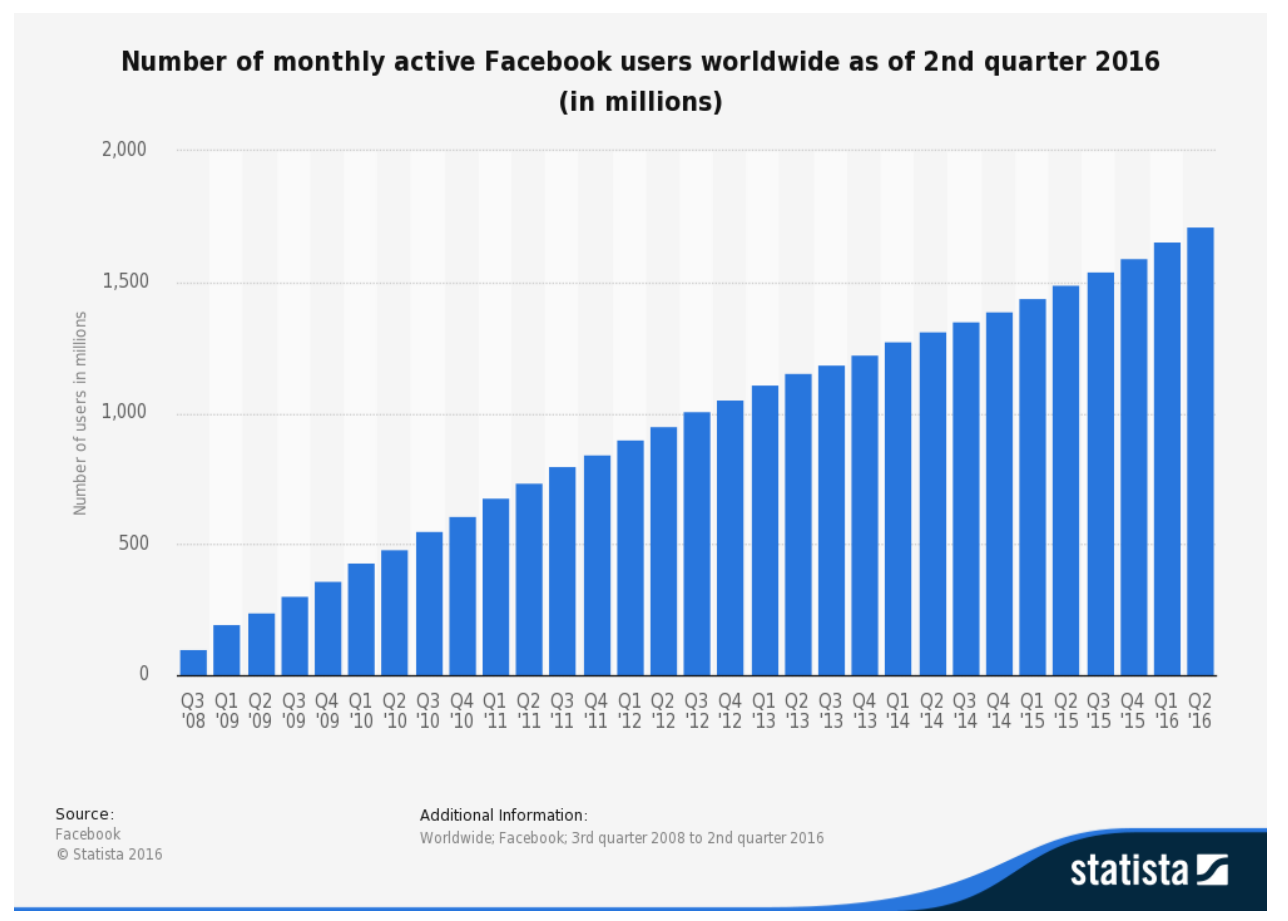

Figure 1: Number of monthly active Facebook users worldwide as of 2nd quarter 2016 (in millions) (Source: The Statistics Portal (5)) 
Recent studies specifically focusing on medical students' use of Facebook report that $70.8 \%$ of UK medical students used social networking sites (6), $64.3 \%$ of medical students at one US university had Facebook accounts (7), and $100 \%$ of medical students at the University of Ottawa, Canada had presence on SNSs in particular Facebook (8). With this information on hand, it is evident that a growing number of medical students are using social networking sites like Facebook.

However, it is unclear whether student's use of Facebook for learning is effective or appropriate (9). The casual and personal aspects of student's Facebook use may preclude or exclude teachers' involvement, so students may formulate learning goals that are tangential to formal curriculum (10). Student Facebook users may create many weak connections with each other but find it difficult to develop these into more supportive peer relationships (11). Facebook and social media use in general may become addictive (12).

This study sought to explore the students' use of social media, in particular that of Facebook groups in medical education at the University of Ottawa.

\section{METHODS}

\section{Study Structure and Statistical Analysis}

Pre-clerkship medical students $(n=160)$ were surveyed regarding the trends of use of SNSs as an extracurricular way of enhancing their learning experience. The survey consisted of 20 questions including Likertstyle, multiple choice, yes/no, ranking, and short answer questions. The survey was built using Google Drive forms and statistics were built using Google Drive analytics with the free Spanning Stats module.

The survey questions were divided into 13 sections, each of which approached a concern about students' use of social media.
1. Social media use to facilitate learning.

2. The year of undergraduate medical education social media were used the most.

3. The subjects in their studies for which social media were used the most.

4. The time of the year where social media were used to facilitate learning.

5. Perceptions of social media use in learning.

6. Student's attitude when using social media.

7. Student's posts' preferences.

8. The types of inquiries they made when using social media.

9. Student's attitude while using social media (posting, observing or both).

10. The types of posts they participate with.

11. Their worries when posting the frequency of social media access.

12. The frequency of social media use was the number of times the user accessed SNSs in a given hour, or day.

13. What they like and disliked about using social media in their learning.

\section{RESULTS}

A total of $102(64 \%)$ students participated in the survey. The majority of students (94.1\%) had presence on social networking sites with a predominance of Facebook ( $n=97,95 \%$ and $n=95,93 \%)$ followed by YouTube ( $n=74,72.5 \%$, and $n=69$, $68 \%$ ) in their first and second years of studies respectively. Students used SNSs in their first and second year of studies ( $n=36,35.6 \%, n=45,44 \%$ respectively) and some students stated that they used them equally in both years $(n=20,19.6 \%)$ (Figure 2). 

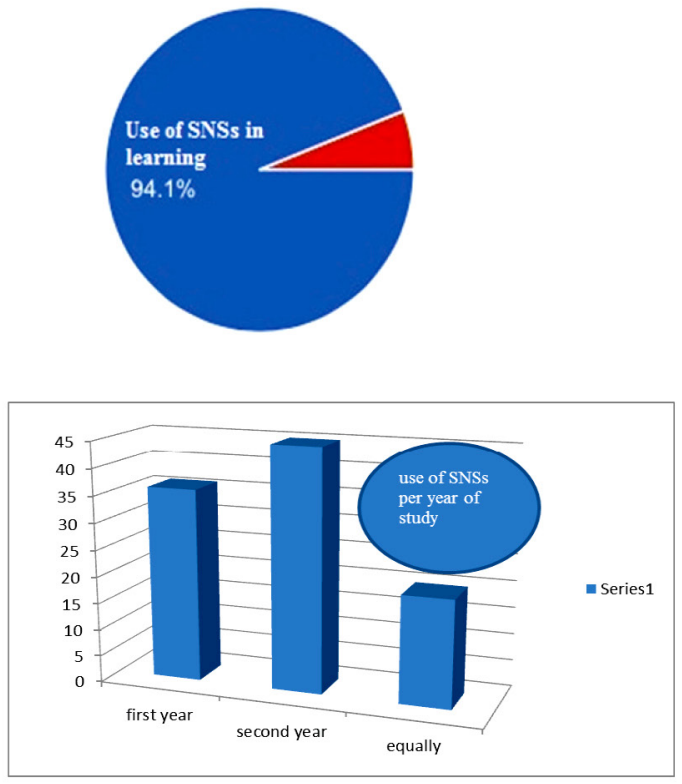

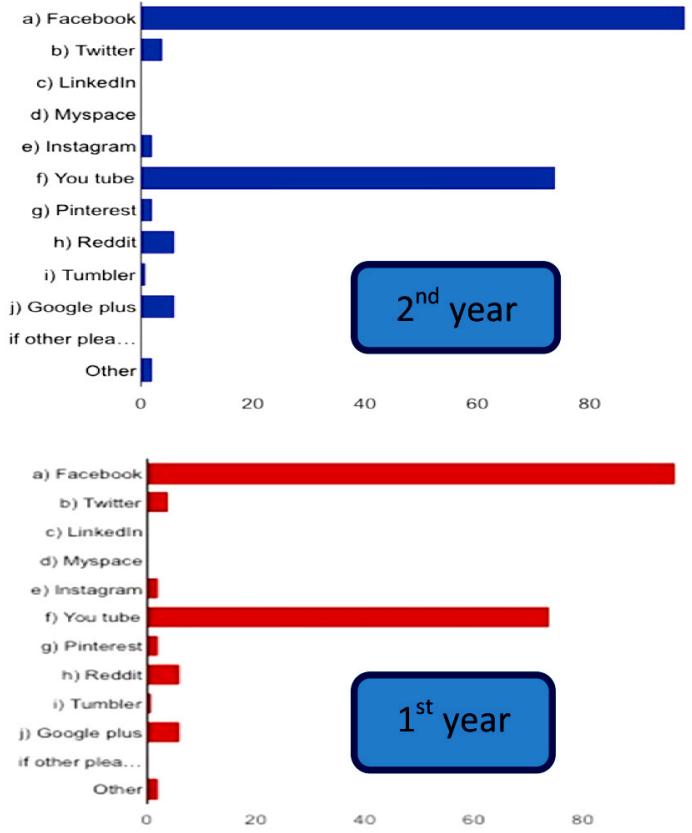

Figure 2: Presence on and types of social media used by students for learning purposes in their first and second year of studies

Table 1: Period of time through the year when students used social media in their learning

\begin{tabular}{lcc}
\hline Period of use of social media in learning & Number of users (N = 102) & $\boldsymbol{n}(\%)$ \\
\hline During the exam period only & 13 & $12.7 \%$ \\
Throughout the year & 48 & $47 \%$ \\
Only during the academic year & 39 & $38.2 \%$ \\
\hline
\end{tabular}

For educational purposes, students preferred to use Facebook groups $(n=58,56.8 \%)$ over Facebook pages $(n=7,6.9 \%)$ while some students $(n=32,31.3 \%)$ did not have any preference for one over the other (Figure 3), and 98 students (96\%) stated that they use those mostly to communicate with their colleagues. Table 1 shows the trend of use of social media in learning throughout the year.

Some students $(n=38,37.2 \%)$ stated that they lost count on how many times they access their account, $17.6 \%$ of students $(n$ $=18$ ) checked it few times an hour, and $10.7 \%(n=11)$ checked it every hour, while $32 \%(n=33)$ checked it a few times a day (Figure 4).
Table 2 shows the number of students using social media to learn for several subjects. Students mostly use Facebook groups to study histology ( $n=29,28.4 \%)$, physiology ( $n=21,20.5 \%$ ), and case based learning sessions $(\mathrm{CBL})(n=16,15.6 \%)$ followed by other subjects.

When it came to communication with their professors and colleagues, students' attitude ranged between observing $(n=52,50.9 \%)$ or posting and observing $(n=48,47 \%)$ (Table 3). 


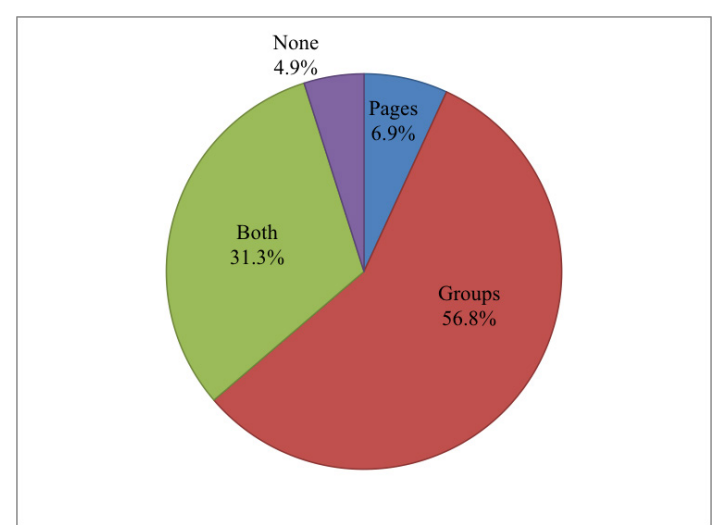

Figure 3: Preference of Facebook groups over pages

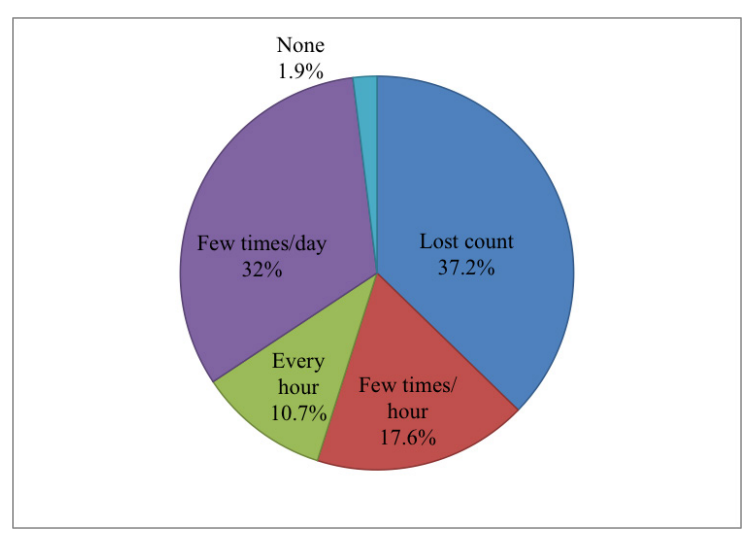

Figure 4: Frequency of logging into their Facebook account

Table 2: The use of social media in learning by subject of study

\begin{tabular}{lcc} 
Subject & Number of students & Percentage (\%) \\
\hline Histology & 29 & 28.4 \\
Physiology & 21 & 20.5 \\
CBL & 16 & 15.6 \\
Embryology & 7 & 6.9 \\
Immunology & 4 & 3.9 \\
Anatomy & 3 & 2.9 \\
Pathology & 1 & 0.98 \\
Hematology & 0 & 0 \\
Pharmacology & 0 & 0 \\
Radiology & 0 & 0 \\
Other & 17 & 16.6 \\
\hline
\end{tabular}

Table 3: Attitude of students when using online groups

\begin{tabular}{lcc}
\hline Attitude & Users (102) & N (\%) \\
\hline Observe & 52 & 50.9 \\
Post and observe & 48 & 47 \\
\hline
\end{tabular}


The types of interaction on social media were mainly answering a question $(n=40$, $39.2 \%)$, making an inquiry $(n=39,38.2 \%)$, posting a social event $(n=38,37.2 \%)$ or an explanatory comment $n=36,35.2 \%$ ) etc. Most of the inquiries were related to exams/tests, content clarification and study resources $(n=53,51.9 \%, n=35,34.3 \%$, and $n=32,31.3 \%$ respectively) followed by other inquiries (Table 4).

When it came to posts' preferences by students, sample tests/quizzes and study guides $(n=63,61.7 \%)$ took the lead, followed by explanatory comments and an answer to a question $(n=52,50.9 \%)$, videos and video links $(n=47,46 \%)$ etc. (Table 5).

Seventy-five percent $(n=77,75 \%)$ of students agree that they can easily navigate FB groups to get the information they need, however $60.7 \%$ of students $(n=62)$ stated they were overwhelmed with the amount of material posted.

Table 4: Type of postings by students

\begin{tabular}{|c|c|c|c|c|c|c|c|}
\hline & Postings & $\begin{array}{l}\text { Users } \\
(\mathrm{N}=102)\end{array}$ & $\begin{array}{c}\text { Percentage } \\
(\%)\end{array}$ & & Inquiries & $\begin{array}{c}\text { Users } \\
(\mathrm{N}=102)\end{array}$ & $\begin{array}{c}\text { Percentage } \\
(\%)\end{array}$ \\
\hline a. & Inquiry & 39 & 38.2 & a. & Exams/tests & 53 & 51.9 \\
\hline b. & $\begin{array}{l}\text { Videos and } \\
\text { video links }\end{array}$ & 33 & 32.4 & b. & Class scheduling & 22 & 21.5 \\
\hline c. & Study guides & 28 & 27.4 & c. & $\mathrm{CBL}$ & 22 & 21.5 \\
\hline d. & $\begin{array}{l}\text { Answering } \\
\text { questions to } \\
\text { posts }\end{array}$ & 40 & 39.2 & d. & Academic advice & 15 & 14.7 \\
\hline e. & Articles & 18 & 17.6 & e. & $\begin{array}{l}\text { Educational facilities } \\
\text { on campus }\end{array}$ & 4 & 3.9 \\
\hline f. & $\begin{array}{l}\text { Sample tests/ } \\
\text { quizzes }\end{array}$ & 32 & 31.3 & f. & Study resources & 32 & 31.3 \\
\hline g. & $\begin{array}{l}\text { Explanatory } \\
\text { comments }\end{array}$ & 36 & 35.2 & g. & Content clarification & 35 & 34.3 \\
\hline h. & Social events & 38 & 37.2 & h. & Sports & 10 & 9.8 \\
\hline i. & Jokes & 33 & 32.3 & i. & Social events & 24 & 23.5 \\
\hline j. & Pictures & 30 & 29.4 & j. & Grade availability & 3 & 2.9 \\
\hline \multirow[t]{3}{*}{ k. } & I don't post & 21 & 20.5 & k. & Housing & 1 & 0.98 \\
\hline & \multirow[t]{2}{*}{ Other } & 2 & 1.9 & I. & $\begin{array}{l}\text { I don't make } \\
\text { inquiries }\end{array}$ & 27 & 26.4 \\
\hline & & & & & Other & 1 & 1 \\
\hline
\end{tabular}

Table 5: Students' posts' preferences

\begin{tabular}{lcc}
\multicolumn{1}{c}{ Posts' preferences } & Users ( $\mathbf{N}$ 102) & n (\%) \\
\hline Inquiry & 41 & 40.1 \\
Videos and video links & 47 & 46.0 \\
Study guides & 63 & 61.7 \\
Answering questions to posts & 52 & 50.9 \\
\hline
\end{tabular}


Table 5: (continued)

\begin{tabular}{lcc}
\hline \multicolumn{1}{c}{ Posts' preferences } & Users $(\mathbf{N}=\mathbf{~ 1 0 2})$ & $\mathbf{n}(\%)$ \\
\hline Articles & 15 & 14.7 \\
Sample tests/quizzes & 63 & 61.7 \\
Explanatory comments & 52 & 50.9 \\
Social events & 30 & 29.4 \\
Jokes & 29 & 28.4 \\
Pictures & 31 & 30.3 \\
\hline
\end{tabular}

\section{DISCUSSION}

Social media sites such as Facebook, YouTube and Twitter are very powerful media forms that have a huge play in the internet world. Factors that contribute to the rise of new media are increased interactivity, network connectivity, mobility of sending and receiving. Though created for social uses, there is empirical evidence that social networking sites are popular among university students and that students are using social networking sites in connection with their studies. They can watch illustrative recordings on YouTube or create pages on Facebook to speak with their educators and partners, share thoughts, posts, make inquiries, and get up to speed with what they missed in the in class experiences. Students' use of social media is steadily increasing and the gap between older and younger student use of social media is shrinking (13). The use of social media depends on the needs and the community of the students using them, for instance, George et al. (14) found out that Facebook, Twitter and YouTube are the top three social media sites used by students. While Cheston et al. (15) found out that Facebook came third after Blogs and Wikis as a platform used by students to supplement their learning and Grajales (16) stated that Wikipedia is the site most commonly used in the medical community. Our study shows that $94.1 \%$ of students use social media to facilitate learning with Facebook taking the lead as the number one used site by medical students, followed by YouTube, Google Plus, REDDIT, while
Twitter came fifth in order (Figure 2). Gray et al. (17) found that, only one in four students in University of Melbourne used Facebook for educational reasons. Another study done two years ago by El Bialy et al. (18) found that only $64 \%$ of students at the faculty of Medicine, University of Ottawa were using Facebook to facilitate their learning compared to $94.1 \%$ in the current study which means that social media is gaining more popularity amongst students as a learning tool. The study shows that there are characteristics in social media that let them more acceptable by students and faculty. Medical students at the University of Ottawa prefer to use Facebook because unlike other platforms, they don't need to friend their professors to be able to communicate. They can restrict who have access to their home page and personal information. Moreover, it is more accessible and more user-friendly than other platforms, with easier interaction and more flexibility, and unlike Twitter for example, there is the option of communicating via groups where discussions are more private and focused. Earlier in 2007, Boulos and Wheeler (19) stated that Facebook groups have been suggested as an environment to teach key information and communications technology (ICT) skills for professional practice. I do remember a few years back when I created a FB group for my class, students were intrigued and some of them were even uncomfortable. A few years after and on the first day of school, I heard one of the students asking his colleagues if they already joined the case based learning (CBL) group on Facebook. 
Students create interest groups on Facebook, where they interact and communicate with their peers. In accordance with Saparova et al. (20), our results show that most of the students' inquiries were related to exams and study resources (Table 5). Some of the professors trying to reach out to the students in their social media habitat created pages and groups to communicate with them. The groups taking the lead in use by students were histology, physiology and case based learning sessions (Table 2), students stated that they use social media for those particular subjects because the material posted gets them engaged. With 1.7 billion users as of July 2016, there is no doubt that Facebook is spreading like wildfire amongst diverse community of users including students at different education levels. According to a Facebook spokesperson, approximately 297,000 Facebook members identify themselves as faculty or staff, students perceive this as an attempt from professors to foster a positive relation with the students which may have a positive impact on the students' outcomes (21). A study done by El Bialy et al. (8) showed that although the majority of educators $(79 \%)$ had presence on social networking sites (SNSs). Only 33\% used them in their teaching. It means that some $77 \%$ faculty lack interest in using social media in education; this contrasts with findings on students' willingness to integrate technologies. In sum, students are willing; faculty members are not. Educators who engage into using social media in their teaching are most likely the early adopters of innovations who are willing to take risks and try new technology.

Students have a tangential line of using Facebook other than communicating with their professors, it is a platform where they socialize with each other and an environment for them to supplement their learning, these results are in accordance with Selwyn (10) who stated that the casual and personal aspects of student's Facebook use may preclude or exclude teachers' involvement, so students may formulate learning goals that are tangential to formal curriculum. SNSs are a valuable resource to facilitate student learning. And with the high number of students using them in learning, there is no other way to think that these internet based technologies are not here to stay. Facebook is the most popular platform used by students at the University of Ottawa and it is the most popular SNS amongst social media users worldwide. The easiness of its use is why Facebook is going viral amongst this community of students.

Social media have the advantage of increasing students' collaboration and interaction with their peers, there is richness of resources and immediate answers to one's inquiries. The materials posted can be generated by educators for learners or by learners for learners and. They empower students to get the material they missed on the off chance that they were not able to come to class. Universities don't even have to convince the students of their value, they are already using it, they almost all have the apps installed on their smart phones and they receive push notifications. One downside of social media is distraction and sharing inappropriate content, that is why educational institutions have to implement guidelines to regulate the use of SNSs in education.

Educators are encouraged to implement them as a part of their teaching; they have to find the way to engage their students and meet their expectations and align the material posted with the learning objectives. Students on the other hand are encouraged to set the line between socialising and learning.

\section{CONCLUSION}

Social media websites are platforms where online communication takes place and their use in learning is increasing steadily; it has the privilege of overcoming the time and place restriction. The newer generations of students grew up with the internet and they 
use it in all the aspects of their daily life. They don't remember a time where internet and social media did not exist. Apart from their use in socialising, SNSs are gaining a wide popularity in medical education with Facebook being the home base for most of the users. Social media are contemporary and efficient communication tools that educators cannot overlook; the challenge is to choose the right platform, the amount and quality of the information shared to ensure optimal benefit and collaboration of the students.

\section{REFERENCES}

1. Lenhart A, Purcell K, Smith A, Zickuhr $\mathrm{K}$. Social media and mobile internet use among teens and young adults. 2010. Available from: http://www.pewinternet.org/ Reports/2010/Social-Media-and-YoungAdults.aspx

2. George D, Dellasega C. Social media in medical education: two innovative pilot studies. Med Educ. 2011;45(11): 1131-62. https://doi.org/10.1111/j.13652923.2011.04124.x

3. Supe AN. Networking in medical education: creating and connecting. Indian J Med Sci. 2008;62(3):118-24. https://doi. org/10.4103/0019-5359.39616

4. De Leng BA, Dolmans DHJM, Muijtiens AMM, van der Vleuten CPM. Student perceptions of a virtual learning environment for a problem-based learning undergraduate medical curriculum. Med Educ. 2006;40 (6):568-75. https://doi.org/10.1111/j.13652929.2006.02484.x

5. The Statistics Portal. 2016. Available from: https://www.statista.com/statistics/264810/ number-of-monthly-active-facebook-usersworldwide/

6. Sandars J, Schroter S. Web 2.0 technologies for undergraduate and postgraduate medical education: an online survey. Postgrad Med J. 2007;83(986):759-62. https://doi. org/10.1136/pgmj.2007.063123
7. Thompson LA, Dawson K, Ferdig R, Black EW, Boyer J, Coutts J, Black NP. The intersection of online social networking with medical professionalism. J Gen Intern Med. 2008;23(7):954-7. https://doi.org/10.1007/ s11606-008-0538-8

8. El Bialy S, Jalali A. Go where the students are: a comparison of the use of social networking sites between medical students and medical educators. JMIR Med Educ. 2015;1(2):1.

9. Mori I. Great expectations of ICT: How higher education institutions are measuring up. Research study conducted for the Joint Information Systems Committee. London: Joint Information Systems Committee (JISC); 2008.

10. Selwyn N. Web 2.0 applications as alternative environments for informal learning: A critical review. Paper presented at the OECD-KERIS International expert meeting - Session 6 - Alternative learning environments in practice: Using ICT to change impact and outcomes, May 2007, Cheju Island, South Korea. [cited 2009 March 3]. Available from: http://citeseerx. ist.psu.edu/viewdoc/download?doi= $0.1 .1 .117 .9470 \&$ rep $=$ rep $1 \&$ type $=$ pdf

11. Ellison N, Steinfeld C, Lampe C. The benefits of Facebook 'friends': Social capital and college students' use of online social network sites. J Comput Mediat Commun. 2007;12(4):1143-68. https://doi. org/10.1111/j.1083-6101.2007.00367.x

12. Bugeja MJ. Facing the Facebook. Chron High Educ. 2006;52(21):C1.

13. Smith SD, Caruso JB. The ECAR study of undergraduate students and information technology. 2010. Available from: https:// net.educause.edu/ir/library/pdf/ers1006/rs/ ers1006w.pdf

14. George D, Rovniak L, Kraschnewski J. Dangers and opportunities for social media in medicine. Clin Obstet Gynecol. 2013;56(3):10. https://doi.org/10.1097/GRF $.0 \mathrm{~b} 013 \mathrm{e} 318297 \mathrm{dc} 38$ 
15. Cheston C, Flickinger E, Chisolm MS. Social media use in medical education: A systematic review. Academic Medicine. 2013; 88(6):893-901. https://doi.org/10.1097/ ACM.0b013e31828ffc23

16. Grajales FJ, Sheps S, Ho K, Lauscher HN, Eysenbach G. Social media: A review and tutorial of applications in medicine and health care. J Med Internet Res. 2014; 16(2):e13. https://doi.org/10.2196/jmir.2912

17. Gray K, Lucas A, Kennedy G. Medical students' use of Facebook to support learning: Insights from four case studies. Med Teach. 2010;32:971-6. https://doi.org/1 0.3109/0142159X.2010.497826

18. El Bialy S, Jalali A, Jaffar A. Integrating Facebook into basic sciences education: A comparison of faculty administered group and page. Aust J Anat. 2014;1(3):7.
19. Boulos MK, Wheeler S. The emerging Web 2.0 social software: An enabling suite of sociable technologies in health and health care education. Health Info Libr J, 2007; 24(1):2-23. https://doi.org/10.1111/j.14711842.2007.00701.x

20. Saparova D, Williams J, Inabnit C, Fiesta M. Information behavior shift: How and why medical students use Facebook. Proceedings of the American Society for Information Science and Technology 2013;50(1):1-4. https:/doi.org/10.1002/meet.14505001171.

21. Roblyer A, McDaniel M, Webb M, Herman J, Witty J. Findings on Facebook in higher education: A comparison of college faculty and student uses and perceptions of social networking sites. Internet and Higher Education. 2010;13(3):134-40. https://doi. org/10.1016/j.iheduc.2010.03.002 